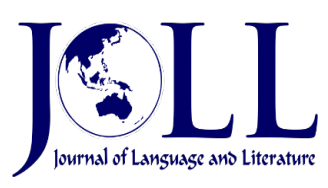

Vol. 21 No. 2, October 2021, pp. 376-390

DOI: 10.24071/joll.v21i2.3241

Available at https://e-journal.usd.ac.id/index.php/JOLL/index

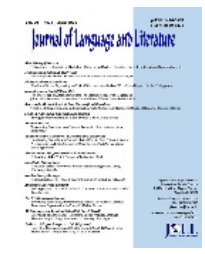

This work is licensed under a Creative Commons Attribution-ShareAlike 4.0 International License.

\title{
Racism towards Black American: Intersectionality in Constructing Social Racist through Poetical Depiction by Langston Hughes and Amy Saunders
}

\author{
I Gusti Ayu Sundari Okasunu, Ni Luh Nyoman Seri Malini*, Made Detriasmita \\ Saientisna \\ seri.malini@unud.ac.id \\ English Department, Faculty of Humanities, Udayana University, INDONESIA
}

\begin{abstract}
In this research, the development of racism based on the different formations of socio-cultural and historical aspects was the standpoint that was shown by the interpretation of poetical depiction of meaning and messages. The gap between Langston Hughes in "I, too, sing America" (1926) and Amy Saunders in "You're not Black" (2019) as the data advocates for racist transformation in natural past and present American socialization. Several critical studies have examined the racial issues reflected in poems however they didn't elaborate on racism specifically rather than segregation and discrimination although racism is classified in several types. Moreover, the critical studies have been done only analyzed the racism happened on the past while this study compares the past and present racism as the concern of social construction among black American as the target of unfair treatments. The descriptive qualitative method using documentation, descriptive analysis, and note-taking technique was used to identify and elaborate meaning correlation with racial issues in the poems. This research aimed to classify the figurative language and its meaning related to racism while illustrating the development of racism from the perspective of sociocultural and historical aspects that influenced the poets and their poetry. Theory of Critical Race was used to demonstrate that racism was developing in a different formation. The research has found the interconnection between historical values of slavery system constructed stereotypes of black people as minor American. Social construction formed a cultural differentiation which led to segregation and discrimination towards black in any form of everyday aspects.
\end{abstract}

Article information

Received:

26 March

2021

Revised:

15 May

2021

Accepted:

8 June

2021

Keywords: racism; poetry; Langston Hughes; Amy Saunders 


\section{Introduction}

Literature has taken a role in every expression in written things whereas the other documents cannot be classified as such (Klarer, 1998). Literature introduces people to new experiences means literary work immediate literary environment shaped by given social group and epoch (Morris 2005, p.81) Literary work tends to imitate the world that proceeded by text where it is capturing critics of its social phenomenon being reflected as the main basis. Literature enables people to see through the other's lenses of perspective in which triggers the readers to reflect upon their life. Racism is a common issue that is depicted in literary works.

Racism is a situation in which a group of people feels superior above the other group of people. Wilson $(1999$, p. 14) stated that a root of racism is an ideology of racial domination which means that the presumed biological or cultural superiority of one or more racial groups is a means to justify or prescribed the inferior behavior in the social position of another group. Racism as a process of socialization is the operation of certain levels of racial differentiations which is 'racialized' the downplaying diversity within both dominant and subordinate groups (Satzewich, 2011). The practice of racial discrimination leads to racism happen following the American social perspective where it is also influenced by the historical values that this community has been held on for several years. The impact of this social racist is the shape of human culture to live an unequal life for the minor group. The term Racism is developing along with the situation of America nowadays.

Even though time has passed and social life has improved, the practical ways of racism also developing correspond to the newest sociological term. The case that proves this term is the death of George Floyd who was arrested shortly after allegedly using a fake $\$ 20$ bill at a local Cup Foods on May 25, 2020, because of police custody while another White suspect of murder got compensation for his case. Besides the demonstration, there are several ways to express protest against racism such as depicting racism through poetry.
Poetry is a criticism media of life under the condition fixed for such criticism by laws of poetic truth and beauty. Poetry is a spontaneous overflow of powerful meaning in which expresses through written things (Lennard, 2005). The special grammar of poetry emphasizes more meaning and deep feeling from the writer where in particular the ideas of the poet must be the realization of his or her experiences. The poet has a strong power to influence readers through their poetry. As mentioned by Poetry Foundation, there are more than a million poets who are enthusiastically writing against race and discrimination. Two of them come from different ages but are famous for their openminded poetry to describe racism. They are Langston Hughes and Amy Saunders.

Langston Hughes was an American poet, novelist, playwright, and short-story writer who was a Black Man born in Joplin, Missouri. He was famous against racism through his poems and novel in the 1969s. Meanwhile, Amy Saunders was one of the 15th winners of the Foyle Young Poets of the Year Award 2019. Her poem won the prize as it depicted racial development in the 21st era. She has shown the modernization of racism along with social development and stereotypes through her ironical yet metaphoric poem.

The sense of the metaphoric poem is derived from the figurative meaning that strengthens the poem to gather its ideas powerfully. According to Perrine (1992), figurative language is the used of certain forms of language to communicate such as daily conversation, articles in the newspaper or journal, advertisements, novels and poems, etc that afford readers with the imaginative pleasure of literary works, bringing certain imagery, making something abstract to be concrete and sensuous, representing emotional intensity along with information and meaning, and the way to saying much in a brief. Simply saying, figurative language is the figure of speech consist of certain thoughts as the meaning (Bartczak, 2016). Knickerbockers and Reninger (1963) in their book entitled "Interpreting Literature" stated that figurative language derived from the word "Metepherein" from Greek which means to carry meaning beyond its literal meaning. 
From those metaphoric meanings, the poet used to represent racism implicitly.

The assumption of race is shaped by wider societal variable forces (Oni \& Winant, 2004). The whole field of racism cannot be covered only by the theory and practice but also by the nature of racism itself. Today, racist is a geneticist category whereas in the past it was a legal one. Racism is regarded as a doctrine and defined as the theory of inequality of races. Racism is a situation in which a group of people feels superior above the other group of people.

In recent times, studies on racism have become the foundation to identify human social systems and interactions in the eye of the cultural diversity of origin. Black poets as the pioneer of black voice have engaged in the illustration of important equal identity among races. Race as a social categorization constructs the people based on their visual differences which are imputed identification of invisible differences.

A range of critical studies has analyzed the interpretation of racist portrayal through the use of poem. Khosravishakib (2017) wrote in Social Function of Poetry from View of New Criticism that poetry has the function of moral elements and representation. Morality lied their values in the meaning and implicit ideas gathered in poetry. The intention of morality shown by its interconnection with the poet and the social life where the poet has been developing portrayed the personal experiences as the main source of ideas. The language of poetry unconsciously depicted morals and feeling as he highlighted in his research the judgment of social issues in the standard function of poetry.

\section{Duki (2017) in The Essential} Characteristics of Langston Hughes's Poetry and Their Impact on the Congolese Conscience has shown the connection of morality in poetry influences other's moral development. He stated that every poem was written in form of a representation of particular essential characterization. He highlighted the external factors of Langston Hughes's poetry and the way from its figurative sense influence the Congolese. The standpoint of his analysis resulting in the categorization on what way Hughes's I, too destructed Congolese.
Langston Hughes who was famous for his ideas against racism led to an important event of protest through literary work in Harlem Renaissance. He has believed that racism differentiated the act and behavior relied on the assumption of natural biological and social differences in determining people by their races. Along with the idea that racism can be protested through strong yet meaningful poetry, the critical studies on the interpretation of poetical-depiction on racism increasing.

Li and Jun Luo (2018) in A Culturalist Interpretation of the Dark Brother's Sound Bitterness in Hughes's 'I, too, sing America" has stated that the dark brothers have been suffering to be characterized in cultural reality that unavoidably shaping the cultural interaction to be distanced from the white people as they often got impolite cultural awareness and led the deconstruction of superiority from cultural counterparts arrogantly. He found out that Hughes depicted strong resistance in protesting the cultural discrimination that humiliated the bitterness of the dark brother's cultural associations. He highlighted that from the poem of Hughes's perspective, there was an interpretation of black beauty in the profound of poetical expression and representation.

Similarly, Stephane (2017) in "I'm bad man": When Langston Hughes traduces the reflexive bad effects of white people's racism on black individuals who refuse "Feeling blue" in his poem "Badman" or the blues poems has stated that the blues is very important as the part of their cultural development in their relationship with racist. He stated along with the ideas of the morality of poem that Hughes wrote the blues poem to justify the importance for black to overcome and bear the racial injustice they have been through in American society. He found that Langston Hughes's poem "I'm a bad man" was focusing on the reflexive bad effects of racism from Negro individuality. From the interpretation of the poem, black people have developed themselves stronger around violence and discrimination.

There are two distinct phases in the sociology of racism as constructed by social development and social changes. The first 
phrase defining racism as prejudicial beliefs and attitudes, for example, the income inequality between the whites and blacks could readily be explained used the perception of workplace discrimination, differences in the educational requirement, and legally segregated school. The term racism happened as social processes and construction namely racialization.

Although several studies discussed racism, this research is still relevant because the issue of racism is not common to be discussed in the language and literature field when this phenomenon still exists and happened in our daily life. Moreover, the research conducted on poem is quite rare. The research about poem commonly discussed only the language feature used by the poet. However, this research analyzed in which way the poet represented racism happened or expressed in correlation with the real situation and condition that the writer wanted to draw. This research used Socio-Cultural and Historical aspects and perspectives to strengthen the meaning analysis towards race and racism in poetry. This research also used two different poets who are Langston Hughes to represent the age of the 1920s and Amy Saunders to represent the year of 2019 as a comparison of how far racism developing in each period.

\section{Methodology}

This research was utilizing the descriptive-qualitative method using documentation, descriptive analysis, and notetaking techniques (Miles and Hubman, 2014). The choice of literary works as the data was carefully taken by considering the meaning construction related to racism and the strength of the poems proven by their achievement for years. The data used in this research were the poem written by Langston Hughes (1926) entitled "I, too, sing America" and the poem written by Amy Saunders (2019) entitled "You're not Black". The procedure for data collection was by the library research material from several journals, conference papers, textbooks, and news articles. In analyzing the data, the research used an analytical method where the critical analysis guided by several steps namely; classifying the figurative language and its meaning related to racism, analyzing the relationship between those poetical meanings and types of racism being portrayed, elaborated the connection between poem and its socio-cultural and historical background and comparing the two poems to analyze the development of racism from the past to present.

Several theories are also needed in the analysis to guide the explanation and straightforwardly keep the analysis on its standpoint. There was Critical Race Theory proposed by Richard Delgado and Jean Stefancic in 2017 as the main theory and supported by the Theory of Figurative Language proposed by Knickerbockers and Reninger in 1963. Socio-Cultural and Historical aspects also joined the analysis as the external perspective regarding the poet to elaborate how situation shaped the human's mind in literary works and interpretation.

\section{Results and Discussion}

The interpretation of poem can be widely present based on personal knowledge however the term figurative language is used to guide the interpretation to straightforwardly follow the standpoint of analysis.

\section{Racism in Langston Hughes's Portrayal of "I, too, sing America" (1926)}

[1] Line 1

\section{"I, too, sing America"}

This poem started by ironically the notion of self-proclaimed affirmation that the main subject of the poem "I" is the speaker as he was a citizen he is also allowed to sing America. "I" as the subject of the poem can refer to AfricanAmericans who are implicitly represented through the poem by Langston Hughes. The phrase 'sing America' means an act of a citizen that equally has the same role in the citizenship to do and to treat in the same way. It is classified as a metaphor since it is used to create a new sense where the literal meaning and the situation are applied. It is also a comparison and an expression showed in a simple way between the situation that the African-American people have faced and the right of them as a human being and as a citizen in America. 
[2] Line 2

"I'm the darker brother"

The word "I'm the darker brother" has particularly a special image of the speaker that is presented through metaphorical meaning. The word "I'm" obviously pointed at the speaker as he is the main subject and the person who experienced the story which was the poem is about. It is proven by the following words "darker brother". "I'm" which is followed by "darker brother" brings up the assumption of self-recognition from the speaker as he is part of the darker family.

[3] Line 8-10

"Tomorrow,

I'll be at the table

When company comes"

Tomorrow has a meaning for the day after today, one day after today, or probably the time we cannot predict in the future. In accentuation for how long is the period that they will be at the table is not being predicted by Hughes however Hughes does not want to discourage his darker family about their hope. "Tomorrow" is chosen as the replacement of the word that means "time will heal" so this line stands for Langston Hughes's hope and beliefs for justice to black Americans. The line says "I'll be at the table" metaphorically representing the position, status, and power within persons in social construction. Moreover, Langston Hughes stand for personal self-beliefs to dispute the third line by stating that African-Americans will have to sit at the same table which means will speak as loud as the whites, will act as brave as the whites, and will live the life with their wisdom not to be afraid and being under the other person, but stand with their own feet on their own country, tomorrow.

\section{[4] Line 15-17}

"Besides,

They'll see how beautiful I am

And be ashamed-"

These lines begin with the self-confidence of the speaker who declares himself as someone who will be 'bloom' as beautiful as he is and all of the people who see him lowly would be ashamed of what they have done to him. The beauty of themselves through their color is shown in line 16 which says "They'll see how beautiful I am". This line shows that the time for them to be admitted as an American citizen is now coming and they have their rights to grow up and develop themselves to live life with wisdom. This line also tells the self-conception of the black people as American that lead the whites to the conclusion of what they have done is wrong and they have to be ashamed of the fact that the people they were discriminated of and they have isolated are growing up and stand with equal confidence and strength as well as them. This line used a metaphor and says "how beautiful I am" is not exactly mean the appearance of the speaker because the word "beautiful" there attach many meanings. According to this poem, Langston Hughes describing the "beauty" in the sentence "They'll see how beautiful I am" as the declaration of pride and conception of black America. The line "how beautiful I am" means that black America can grow older and bigger than the whites and can reach real happiness with a brighter and better life than the whites in an equal situation.

\section{[5] Line 18}

\section{"I, too, am America"}

The last line begins with the repetition that same as the beginning of the poem. Moreover, the last line expresses the affirmation to emphasize that the black people already have the recognition as the American and free from racial discrimination. This line also has a function as a conclusion or the ending of life as happy life for the AfricanAmerican people. 


\section{Storyline of Langston Hughes's "I, too, sing America"}

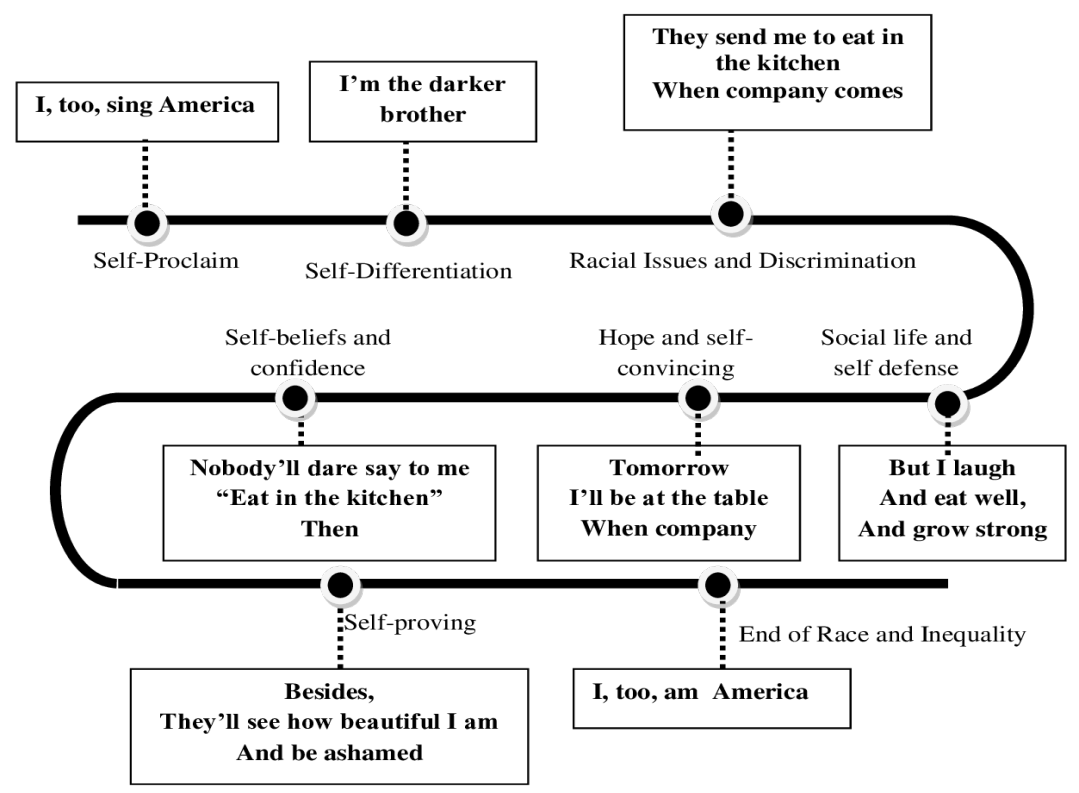

Figure 1. Storyline of Langston Hughes's poem "I, too, sing America"

The diagram above shows the fluctuation of a black speaker as he is representing the darker brother from the spirit of anti-racism. It has increased when seen by the diagram firstly the speaker affirms himself as American then growing up to have a self-believe rely on a better future for black people.

Intersectionality is the Name of Darker Brother Construct Social Racism in Poetical Depiction of "I, Too, Sing America" by Langston Hughes. The term intersectionality is a closeminded perception that creates stages over society. In the 1920s when Langston Hughes was alive, this term is well-known as caste and social system. The caste itself leads the growth of White supremacy where the black people should have and always be under the legal rule that White is the owner of Black people because of the slavery system. Even though in Langston Hughes's era there is no slavery however the perception and the culture of slavery still hold a role. Black people have no power as White. This term shows in Hughes's poem "I, too" line number 2 which says:

\section{"I'm the darker brother"}

(I, too, sing America Line-2)
The word darker has been explained before as a meaning of skin color and racial identity. However, some people thought this word was only the representation of race in Hughes's perspective. Indeed, the word "darker" is derived from the cultural perspective from the history of Racism itself. The relationship between race and physical appearance is undeniable at the same time uncertain. It becomes a subject to distinguished people. As Rayford Logan has said, there would be the darker skin with tightly curled hair, thick lips, and broad noses among the Negroes. Therefore, the term "dark" was created to identify people. The term "dark" is used to classify people in their social life activities. As time passed by, they used it as a cultural perspective that constructs their social life and group. The belief that one with darker skin color belongs to the low-class society makes a thick line that is classified as the intersection between white and black people in America. They used it as a culture that must have a continuation perspective so that the race cannot be mix and White still has the power. On the other hand, they used the term "darker" as a racial identity to symbolize a low-class community.

The term "darker" that is part of intersectionality represents in Langston 
Hughes's poem is all based on the sociocultural experience of the poet and his friend. Langston Hughes and the other black kids were not allowed to swim at the YMCA or join the Boy Scouts. The black people and their kids which were called Colored Boys which has the same meaning as "darker brother" at that time were not allowed to take the grammar class, play at the school teams, and were forbidden to play against whites. At the Patee Theater on Massachusetts Street, for example, there was a sign that said "NO COLORED ADMITTED" in the box office. Little Langston and other black boys could only be listening to the movies wistfully while the other whites friend talked about the latest episodes of Charlie Chaplin and Mary Pickford.

The term "No Colored Admitted" was created as the cultural perspective where it is followed by social construction. Thomas Sowell (1994) has said in the book "Race and Culture: A World View" that history was recorded because it was representing peoples and nations however the patterns that emerge in history were the pattern of culture(2006). People submitted the term of color as the cultural pattern on the way they distinguished groups within the community. Langston Hughes was living in a period where the colored culture led his society to the new reconstruction of what people called racial differentiation. Moreover, those intersections then lead to the form of social construction as shows in Hughes's "I, too, sing America" line 810 which says:

\section{"Tomorrow, \\ I'll be at the table \\ When company comes"}

(I, too, sing America Line 8-10)

Some poems protest the social conditions of black specifically; some are boldly declarative of the beauty and dignity of the race; still others-perhaps the most reveredtranscend both angry protest and bold declaration to affirm quietly the dignity and historicity of blacks. Hughes reacted as both artist and social critic to the primitivism ferment of the early twentieth century. Hughes's position was of course complicated by his racial identity, which made him an object and not merely an observer of primitivism representations. As a poet, Hughes constantly tries to illustrate how formal qualities may assist an act of engaged social criticism. Despite the use of words that divide us into the "transparency" of poem meaning and convey us to believe that we are taking an unmediated view through a windowpane of a world outside the poem, Hughes offers historical knowledge by directing our attention to his careful arrangement of words on the page. His style often fluctuates the language formation in the poem's social perspectives. Hughes's speaker assumes two points of view: observer and victim.

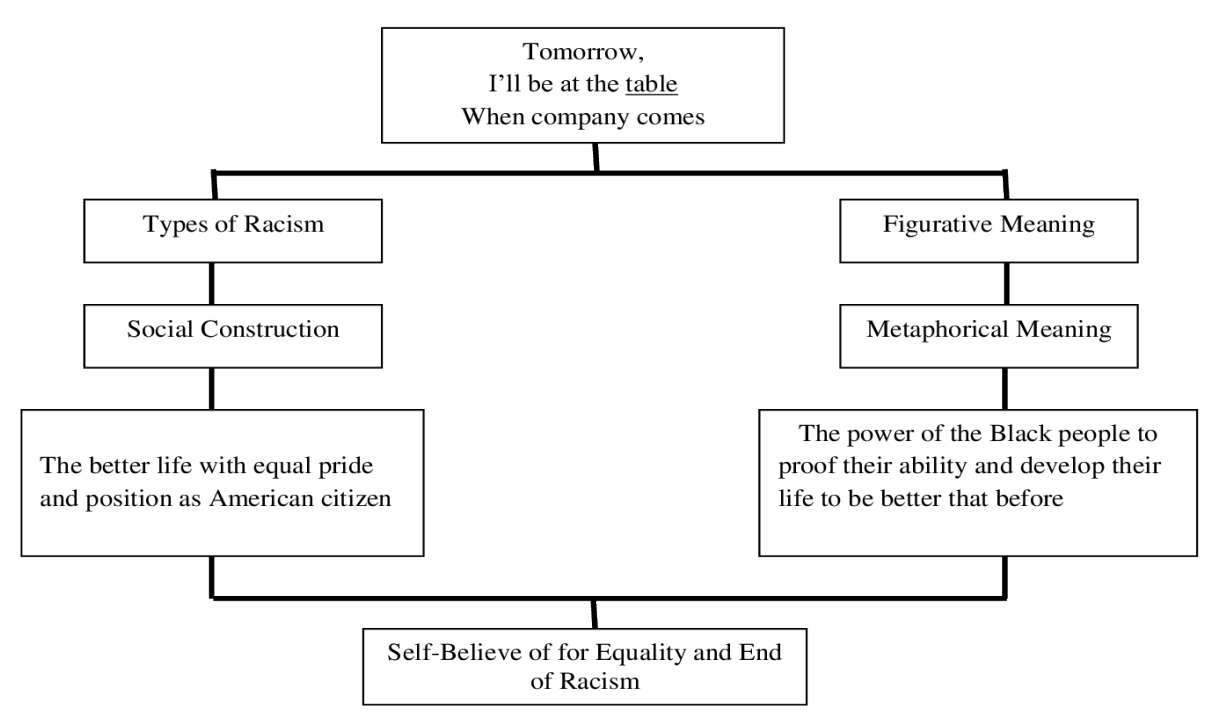

Figure 2. Meaning Description of Black people Self-Believe in Langston Hughes's "I, Too" 
From the diagram above, the speaker shows that the only way to completely free from the cultural subjugation, domination, and manipulation of the cultural counterparts of dark brothers is to be aware to develop their cultural persistence through the successive enhancement of their awareness of cultural subjectivity through cultural communication, cultural negotiation, and cultural subversion instead of cultural dependence, cultural submission, and cultural concession. "No matter how hard they have to suffer, the day when everything is changing to be better will come soon" is the key point for line 8 and line 9. The ninth line which says "I'll be at the table" representing the future using the modal "will" and equality from the word "be at the table". The word "table" here has many interpretations such as:

- "table" is a place where two or more people sit and communicate with the same posture and body positions to describes the social equality status.

- "table" has a role in social life because when people talk at the same table it means they have the same class or even there is no class classification among them.

- "table" is human rights because Western people metaphorically call a table the symbol of justice and rights.

Furthermore, Langston Hughes uses repetition for the line four and ten, as says "when company comes". The line with the notion of "company" in it has a metaphoric meaning identifying such as the group of white people, the highest class person, the power holders, and rich man/woman in the community but all of them are the white American which shows the existence of social determination that construct the social interaction in American society.

\section{Racism in Amy Saunders's Portrayal of "You're not Black" (2019)}

(6) Line 3-4

"I eat with a knife and fork"

"You're not black if you don't use your hands to eat"

Saunders in the third line depicted the speaker eating with the table manner ethics using the cutlery to represent and show the level of equality. She uses situational irony where the black people use cutlery to not being underestimated as African-American. This is considered as situational irony because although the black people are already got their human rights, the stereotypes that develop in American society force them to fall into a trap of wanting to be the same and act the same as the white people so that they would not be discriminated base on their racial identity.

\section{(7) Line 11-12}

"Yet, I am familiar with the beat of pounding

Pounding of sugar cane, the whipping of backs"

In these two lines, Saunders uses the term metaphor to represents the gap between the capitalist as the social holder and the slaves in the working-class community. The statement of the eleventh line is strengthened by the depiction of the working field present in line twelve. The line pounding of sugar cane, the whipping of backs represents yet the time has passed, the historical values when economical conditions for the black people was imbalance and forced them to be right in working classes were at another low point, and there was intense labor and racial strife whenever they are talking about the black American existence in the community.

\section{(8) Line 13-14}

The cries and screams of my ancestors

Ring loud in my head centuries later

Racial discrimination is assumed to be the most thing from the past that whites may assert as the 'African paranoid' since they often give them the advice that slavery happened hundreds of years ago but the strong effects of the racist that happened in the past still following the next generation. These lines represent their self-rejection towards the old perspective about slave and enslaved however metaphorically they also cannot neglect the fact that whether free or enslaved, the African Americans were not able to be the pure citizens of America because of the large number of white represented in setting the formula for enumerating the population. 
(9) Line 17-18

And I'm sorry if I don't live up to your 'black norms'

But I live in a world with segregated dorms

The use of ironic language continuing in the representation of black matter and black social construction in lines seventeen to eighteen where there is the emergence of two racial terms used by the white people and black people to implicitly portray racism. The first one is the term "black norm" mentioned in line seventeenth where it is originally derived from the whiteness perspective on the social and community law they made up in the past to maintain the position between black and white to be always the same in white dominancy. Black norms refer to the preference for whites that makes it is harder than the norm and social construction practiced in American life can be proved as discrimination outlawed by civil rights.

Carefully considered, the black norm can be also seen as an examination to reveals a pattern to what is seemingly arbitrary as racial action. In sociological terms, people internalize certain values and norms that induce them to participate in, accept and reproduce relations of production however in the term of the black norm, white American forced what must be internalized in addition to make white values as the highest role and the black American participate as the servant to accept the status they made for them. And bound up with such representations are certain societal norms, gender roles, attitudes towards certain groups, etc., which may be disseminated and normalized or satirized that could be seen as the process of interpellation of Ethnic identification.

The meaning of "I don't live up to your black norm" represent the great rejection of the active presence of experience which forms the schemes of perception, thought, and action that tends to guarantee the 'correctness' of the constancy of formal rules in the explicit norm of white supremacy. There is no term of a black norm in the historical values because if the state is racist, it is racist to everyone; it is merely more difficult for white people to see this because part of the racism of the state is to treat and promote whiteness as the norm. They ignored the fact of humans and norms but created the white norm to rely on the invisibility of whiteness and the focus on blackness as particular and deviant. This obscures the fact that whiteness is just as integral to the mechanisms of racism (in the same way that homophobia relies on homosexuality as the defining identity of gays and lesbians and obscures the particularism of heterosexuality). Saunders uses the term 'black norm' where the speaker rejected to be live on as an allusion to the formation of social classes that violate the human norms to create a social structure in which white people hold on to the power strongly over the existence of black people.

Saunders represents the sense of incompatible norm with its purposes in implementing the norm itself. She continues to strengthen the situational irony faced by the African American in the next line saying "But I live in a world with segregated dorms" to represents the segregation. Saunders uses irony in term of situational irony seen by the condition she depicted in line seventeenth that the speaker does not want to live under the domination of whiteness however the eighteenth line depicted the situation where the speaker only rejected to accept to live under the norm that white people created for them and still they live in the segregated norm as the part of discrimination and segregation. The term 'segregated dorm' brought by Saunders in this line implicitly referring both spatial and mental segregation which is creating non-cooperative communal structures but stark the internal as well as external divisions.

\section{(10) Line 20-21}

I'm not trying to in any way be mean But I live in a society covered in white sheen

Saunders must have a strong belief in the opposition of whiteness. It is depicted in her 20th line in her poem that she representing a speaker who is in an inner conflict between herself and her social life. From the beginning it has been identified that the speaker in Saunders's poem is a black person, struggling for the racist acts in the community. The previous lines have shown the way how black people tried to demand their human rights and how cruel America is. However, like a slow wind after a storm, the speaker in Saunders's 
poem reflected her guilty and her sadness that she never tried to be mean but society forced her to be mean to protect herself. It is portrayed in the contradiction depicted in those lines that the speaker lives in the society that Saunders metaphorically said as "white sheen" with it are relying on the perspective of racial segregation and white power.

As mentioned by a historical research of the notion "whiteness", the term "society covered in white sheen" which is referring to the notion of whiteness itself depicted by Saunders is the social community that identifies itself as a white and "signifier power". Although there are Human Rights and Declaration of Independence in America, the categorization is something that must be practiced. No wonder the more society changes, the more racial discrimination being practicing. Some are arguing that the term of whiteness and white supremacy in society is formed by the prestige of white people itself.

On another hand, proven by history even the poor whites are praised for their existence. It is different from the places that even the richest black man ever had in his life, still being under the poor white although the society covered it well. As Jeff Forrest has argued that whiteness is conferred upon the poor whites that they certainly have the privileges including all the respect and deference from slaves. Thus formed American society into a land where racism was found for the reason Saunders metaphorically saying "society covered with white sheen".

\section{Storyline of Amy Saunders's "You're not Black"}

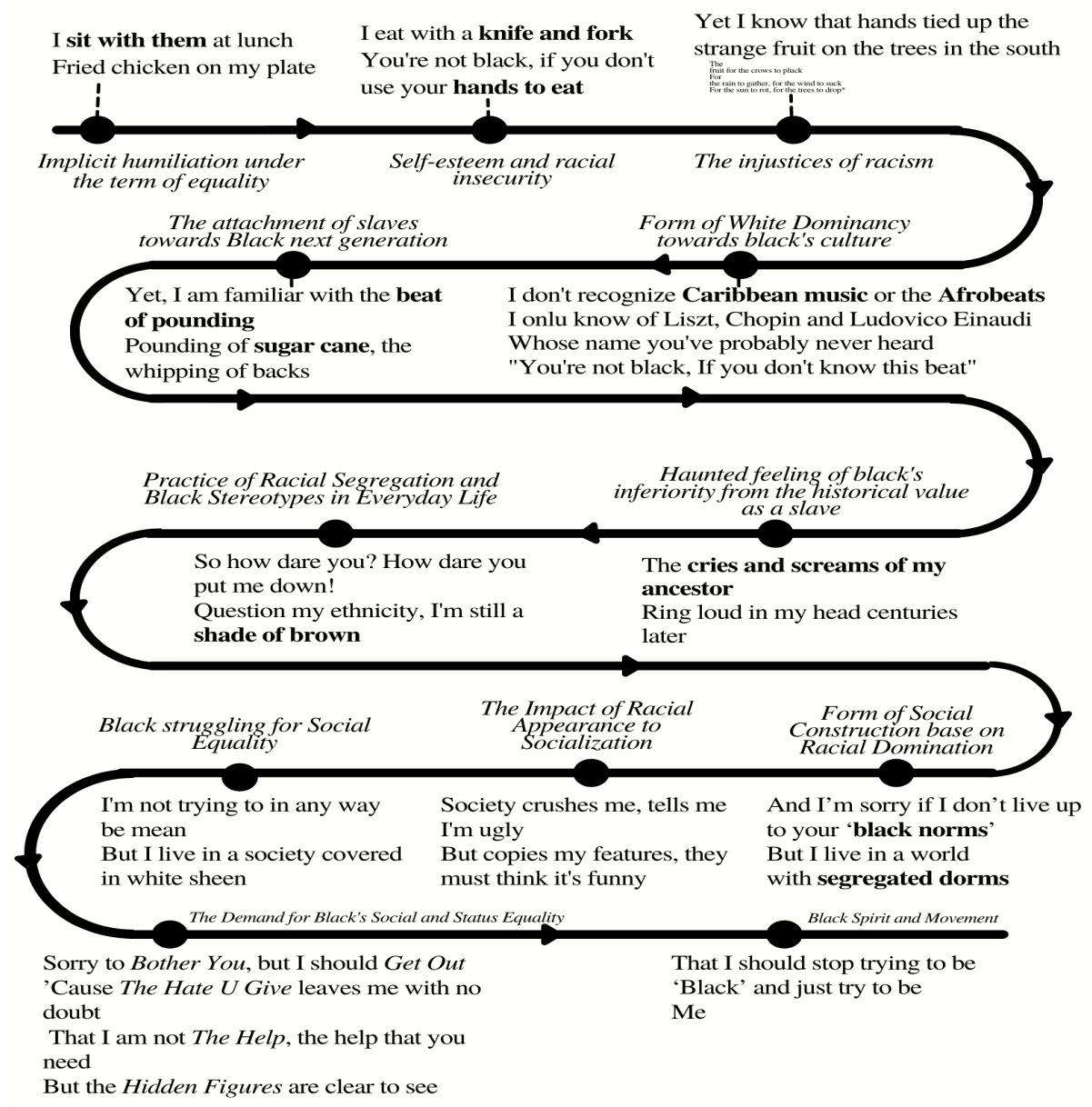

Figure 3 The storyline of Langston Hughes's poem "I, too, sing America" 
The figure shows similarities between Saunders's poem and Hughes's poem story however the differences are shown from the part when the speaker lost her self-confidence regarding racial practices and tried to be as close as white and resemble their culture. Moreover, the poem shows the tendency that black people are haunted by their history. However, the ending of both poems is the same, the rise of black spirit and nationalism.

\section{Intersectionality and Segregation that Construct Social Racist in Present America Depicted by Saunders "You're not Black"}

\section{Line 15-18}

"So how dare you? How dare you put me down!

Question my ethnicity, I'm still a shade of brown

And I'm sorry if I don't live up to your 'black norms'

But I live in a world with segregated dorms

Intersectionality is closely related to segregation. People of color or known as black Americans are separated from the whole American in terms of physical appearance and social status. They were labeled as African American not purely American. The gap line between these two different communities created what people knew as an intersection. In Saunders's poem, the term of this intersection is reflected from the use of metaphorical language "I'm still a shade of brown" which means the speaker acknowledges her entity as black people in a society full of white power. Saunders used the phrase "shade of brown" to emphasize the position and its gap between white and color people, African Americans. As intersectionality has defined the line that separated one bigger community from the other smalls, Saunders expressed the position of black people as to where they are the shadow under the white hands.

The pressure of intersectionality has always being practiced whenever black people tried to get along with the community. In social perspective for example a case happened in history reported in the book entitled "Racist
America: Roots, Current Realities and Future Reparation" mention of brother and sister that were ripped from their homes and imported in chains to Virginia, their name were being ignored as they were called as "negro John" and "negro Mary" without their last name by their new white family who has purchased them for a slave ship. It can be figured out that white people always make a distance by labeling the black people so they won't pass the intersection between them. Therefore, it constructs the social life to be full in the hand of whiteness as mentioned in the lines below:

Line 21-22

"I'm not trying to in any way be mean But I live in a society covered in white sheen

Generally, skin color was the part of a name that was largely used as a conceptual framework among whites to treat most of "blackness" in negative terms. White people named this as racial ideology where they defined themselves as superior groups who are justifiably dominant to make this term rational and placed black people as inferior as the groups who deserve the lower status in American society. Through these lines, Saunders expressed her feeling reflected by the speaker in her poem who's not sick for a society which means she has tried her best to take it back. However, discrimination towards black people was encountered to be stressful for the target of those discriminatory. United States of America is recognizing metaphorically as a house of racism from Saunders 22th line saying "I live in a society covered in white sheen" which means America is a place for those who are white to be free and easily run the society.

\section{Comparison: Intersectionality and Separation between Black and White American Portrayed by Langston Hughes and Amy Saunders}

\author{
"I'm the darker brother" \\ (Langston Hughes "I, Too" line -2)
"So how dare you? How dare you put me down!
Question my ethnicity, I'm still a shade of brown
And I'm sorry if I don't live up to your 'black norms'


But I live in a world with segregated dorms (Amy Saunders "You're not Black" line 15-18)

'Intersectionality is the term where power, privilege, disadvantage, and discrimination are all functioning in the interlocking spectrums of identity (Delgado and Stefancic, 2013). Once a person believes in the term of intersection, it will along with racism created the difficult rejection of gender or sexuality as a category to recognize discrimination. It leads to the implications of the violence and discrimination to reach the higher victims on the black woman. Intersectionality helps to reveal the privilege when someone remembered that intersection is multidimensional where multiple dimensions intersect. As society categorizes someone based on race, it might be that race plays the role as a whole cluster of color, culture, identification, and experience. It also can be concluded that intersectionality itself is related to the hierarchy. Once the hierarchy is made, the problems of social construction become more complex. Intersectionality can be defined as the belief of individual classes and interests.

The term "darker brother" in Langston Hughes's "I, too" deeply representing the brotherhood or root of the family of the darker skin people in America which is the AfricanAmerican. The term "darker" which is referred to skin color is more about the label of personal race and biological appearance belongs to the ancestor. Dark skin color is something that is passed down genetically by the ancestors and something inevitable because it involves heredity. No one could deny their heredity and must accept it. However, based on historical aspect, the black people or African people have had kidnapped a long time ago in the transatlantic trade slavery. The status when the African first stepped down their feet in America was as a slave and worker. According to Robert Fogel, the developments of the "slaves" in America which grew into a group of African-Americans is based on the "age-old sentiments" on the slavery system where the whites have emphasis with a new race that justified the domination of white over the black and labeled them as "the darker brother" to create a slight differentiation and segregation.
Meanwhile, Saunders within those lines also shows the wall that differentiates the society between the major group and black people the minor. Saunders used the term "black norms" and "segregated dorm" to emphasize the different world black people and white people have had. Normally in history, there was the only term of the white norm since they were the founder of those terms, however, Saunders implicitly does the allusion to protest saying the norm is from the black. On the other hand, these phrases emphasize also the intention that the line says "I'm sorry if I don't live up to your black norms" which means that the black people are never agreed with the intersection white people has made for them. Unfortunately, they have no power to leave the segregated society that they have sick of for years.

Moreover, still related to the meaning of "shade of brown" and "segregated dorms" that indicated the racial separation within society, a New York minister and editor namely Samuel E Cornish has denounced that the lacked price of races is stunning by such term namely "negro" "colored" and "African". The term of segregation to make a distinction between White and Black use from the Langston Hughes era until the present even though they use different types of naming. The intention to label the black people tend to create stereotypes in American society that construct their position in the daily aspects as mentioned in lines derived from both poems below:

\section{"I'll be at the table \\ When company comes" \\ (Langston Hughes "I, Too" line 9 and 10)}

"I'm not trying to in any way be mean

But I live in a society covered in white sheen" (Amy Saunders "You're not Black" line 21-22)

What these lines represent have similarity with what Dickinson, Washington, and other influential white leaders described slavery as creating people who would be cowardly, weak, degenerate, and inferior from their viewpoint that seen African American to be kept and treated as slaves or simply saying it is a natural law of American society. The lines of this part of the poem depicted that by the time there are 
many black and white abolitionist who was aggressively protesting the slavery system which is only lead to sad and sorrow for the life of African American so it still being a consideration and a struggle for the next generation of the black family to survive without being discriminated in American society. The interests of the white racial class have included not only a concrete interest in labor and other exploitation during the slavery and segregation periods but also a concrete interest later on in maintaining the privileges inherited from one's ancestors.

In Langston Hughes's poem, black people tend to seek equality and got no more than little power to be in the same position as whites. They have less power and position based on the construction of social status. It is depicted from the notion table used to represent the hand of human rights. He uses the notion of the table to emphasize the stages there to determine where black people must be and what power whites hold on. People with black skin are considered to be in the lower status where the social development to maintain the power of whites as the highest status.

The strongest belief of separated social life leads to the strongest impact of negative attitudes about "blackness" that are reproduced locally by the major community to identify and strengthen the "whiteness" role. The formation of whom society you are living in clearly depicted by Saunders in correlation to what in 1760s Indian people mostly believe is the color term occur as the markers of clear distinctions between people and their indications of belonging a land. White America does know their land is a land for free but they shape their perspective to not acknowledge the term of land for people yet distinguished their society into black and black to make it divided between the African Americans and themselves as American.

\section{Conclusion}

This paper tried to show the complex practice and the structural development of races from the eye of literary work poetry in different ages. The research resulted in the elaborated analysis of three great parts. Firstly, Langston Hughes and Amy Saunders's poems were depicted meaning that focus on the determination of white and black in American society implicitly emphasized the practices of whiteness in American society as a system of positional status based on the influence of black slaves stereotypes derived from history. Secondly, based on the categorization of racial practice in Critical Race Theory, both poems have represented American society as the bowl of racism where the intention to force whiteness to the black's personality created an effect of white dominancy in every single part of living matter. Lastly, racism in America based on the analysis of Socio-Cultural and Historical aspects as the mean to compare both poems has shown that it was developed from past to present in complex yet implicit intention and construction. The two poets portrayed different soul to be black because Langston depicted black people as they have the spirit to move on and fight for their equality in the eye of human right meanwhile Saunders depicted the black people in the present to lost their self-confidence and seen the advantages to be white so they often pretending to follow the nature of whiteness.

Therefore, the meaning that emphasizes discriminate social construction in America based on racial identity can be presented in the table below; 
Table 1 American Past and Present Social Construction base on Skin Color

\begin{tabular}{|c|c|c|c|c|}
\hline \multirow[b]{2}{*}{$\begin{array}{l}\text { Social } \\
\text { Construct-ion } \\
\text { Indicator }\end{array}$} & \multicolumn{2}{|c|}{$\begin{array}{c}\text { Past } \\
\text { (Langston Hughes's Poem “I, } \\
\text { too") }\end{array}$} & \multicolumn{2}{|c|}{\begin{tabular}{l}
\multicolumn{1}{c}{ Present } \\
(Amy Saunders's Poem \\
"You're not Black")
\end{tabular}} \\
\hline & Black & White & Black & White \\
\hline Social Position & Low Class & High Class & Equal & Equal \\
\hline $\begin{array}{l}\text { Race } \\
\text { Perception }\end{array}$ & $\begin{array}{l}\text { Dogma: } \\
\text { Blackness } \\
\text { (slaves) } \\
\end{array}$ & $\begin{array}{l}\text { Dogma: } \\
\text { whiteness } \\
\text { (company) }\end{array}$ & $\begin{array}{l}\text { Stereotypes: } \\
\text { black as } \\
\text { newcomer }\end{array}$ & $\begin{array}{l}\text { Stereotypes: } \\
\text { white's racial } \\
\text { privilege }\end{array}$ \\
\hline $\begin{array}{l}\text { Socializati-on } \\
\text { within Society }\end{array}$ & $\begin{array}{l}\text { Segregate: minor } \\
\text { small group }\end{array}$ & $\begin{array}{l}\text { Dominant: major } \\
\text { with big group }\end{array}$ & $\begin{array}{l}\text { Discriminate: } \\
\text { physical } \\
\text { appearance }\end{array}$ & $\begin{array}{l}\text { Dominant: } \\
\text { land } \\
\text { ownership } \\
\text { stigma }\end{array}$ \\
\hline $\begin{array}{l}\text { Evaluation of } \\
\text { Environ-ment }\end{array}$ & $\begin{array}{l}\text { Live in an area } \\
\text { that is } \\
\text { predominantly } \\
\text { Black }\end{array}$ & $\begin{array}{l}\text { Live in central } \\
\text { area }\end{array}$ & $\begin{array}{l}\text { Live in middle } \\
\text { income area; }\end{array}$ & Stay-spread \\
\hline
\end{tabular}

From the table above, the differences between past and present construction of social life base on racial identity are significant. The social life construction has been changed from the form of social class into the form of apply new stigma about racial differentiation. In the past, white people maintain their position to dominate social interactions however, white people in the present adopt new stereotypes that stem from whiteness stigma and the notion of white land ownership (racial privileges that white is the owner of America). In the past, Hughes represents different social construction of white and black using a clear distinction of "darker family" and "company". It shows the different classes and social statuses between black and white people. Meanwhile, Saunders represents the different social construction between black and white people using the implicit meaning of "society covered in white sheen" which means an equal society that applies closed racial discrimination. Closed racial discrimination is an act to do racist implicitly as a new habit resulted from the development of old stigma that sees whites are inherently superior to blacks. 


\section{References}

Arango, T \& Friends. (2021, January 11). What We Know About the Death of George Floyd in Minneapolis. Retrieved February 11, 2021 from The New York Times (online): https://www.nytimes.com/article/georg e-floyd.html

Bartczak, K. (2016). The work of the Poem As Figurative Field: Evolution of Figurativeness from Wallace Stevens to Rae Armantrout, In:P. Stalmaszczyk (ed)

Berg, M \& Wendt, S. (2011). Racism in the Modern World. United States: Berghahn Books

Delgado, R \& Stefancic, J. (2013). Critical Race Theory: The Cutting Edge ( $\left.3^{\text {rd }} \mathrm{Ed}\right)$. Philadelphia, Pennsylvania: Temple University Press

Delgado, R \& Stefancic, J. (2017). Critical Race Theory: An Introduction ( $3^{\text {rd }}$ Ed). New York: New York University Press.

Duki, J.M. (2017). The Essential Characteristics of Langston Hughes's Poetry and Their Impact on the Congolese Conscience. International Journal of Language and Literature, 5(2),162-173 https://doi.org/10.15640/ijll.v5n2a17

Essed, P. (1991). Understanding Everyday Racism: An Interdisciplinary Theory. United States: Sage Publication, Inc.

Feagin, J.R. (2001). Racist America: Roots, Current Realities, and Future Reparations. United States: Routledge

Fredickson, G. (2003). Racism: A Short History. New Jersey: Princeton University Press

Hughes, L. (2004). I, too, sing America. Retrieved February 9, 2021, from Poetry Foundation website: https://www.poetryfoundation.org/poe ms/47558/i-too

Johnson, B.L. (2007). Bloom's Modern Critical Views: Langston Hughes- New Edition. New York: Infobase Publisher

Khosravishakib, M. (2017). Social Function of Poetry From View of New Criticism. International Journal of Applied Linguistics and English Literature, 6(2), 14-18

http://dx.doi.org/10.7575/aiac.ijalel.v.6n $.2 \mathrm{p} .14$

Klarer, Mario. (1998). An Introduction to Literary Studies. London: Routledge
Knickerbocker \& Reninger. (1963). Interpreting Literature. New York: New York University Press.

Li, G \& Luo, J. (2018). A Culturalist Interpretation of the Dark Brothers' Sound Bitterness in Hughes's I, Too, Sing America. Studies in Linguistics and Literature, 2(1),27-55. http://dx.doi.org/10.22158/sll.v2n1p27

Miles, M and Huberman, M. (2014). Qualitative Data Analysis: A Method Sourcebook Third Edition., United States: Sage Publications Inc.

Omi, M. \& Winant, H. (2004). Racial Formations, In Gallagher, A.C.(ed) Rethinking the Color Line: Reading in Race and Ethnicity. 2nd Ed. (p.9-15). United States: McGraw Hill.

Rainsford, D. (2014). Studying Literature in English: An Introduction. Third Avenue, New York: Routledge.

Rampersad, A. (2002). The Life of Langston Hughes Volume 1, 1902-1941 (2 ${ }^{\text {nd }}$ Ed). New York: Oxford University Press

Satzewich, V., 2011. Racism in Canada. Oxford University Press, Don Mills.

Saunders, A. (2019) You're not Black. Retrieved February 9, 2021, from The Poetry Society website: https://poems.poetrysociety.org.uk/poe ms/youre-not-black/

Sommer, E \& Weiss, D. (2001). Metaphor Dictionary. Canton: Visible Ink Press

Sowell, T. (1994). Race and Culture: A World View. New York: Basic Books, A Division of Harper Collins Publisher, Inc

Spencer, S. (2006). Race and Ethnicity. Madison Avenue, New York: Routledge

Stephane, B.Z. (2017). "I'm a bad man": When Langston Hughes traduces the reflexive bad effects of white people's racism on black individuals who refuse "Feelin blue" in his poem "Bad man" or blues poem. International Journal of Multidisciplinary Research and Development, 4(11),96-106. Retrievedfrom www.allsubjectjournal.com

Wellek, R., \& Warren, A. (1941). Theory of Literature. Lowe \& Brydone Ltd., London 